Yet with over $\$ 100$ million of their own money already spent, the 733 utilities involved have been pushing for construction to go ahead. The level of jingoism has been high. Visitors to the Clinch River site are given a free coffee mug inscribed "we are fighting for energy independence",. And in a letter expressing their support, 17 members of a group known as Scientists and Engineers for Secure Energy, headed by ex-president of the National Academy of Sciences, Frederick Seitz, gave as one of their reasons that "in view of recent political developments in certain Western countries, particularly France, the Clinch River Project may become the only reliable technological undertaking of its kind in the free world".

But in the end the personal support of Senator Howard Baker has been decisive. As characterized in the House budget bill, the liquid metal fast breeder reactor (LMFBR) will be one of a series of steps designed to bring US breeder technology in line with that of other industrialized nations.

The most recent of these steps has been the successful operation last December of the Fast Flux Test Facility (FFTF) at the Department of Energy's Hanford Reservation in Washington State. Late in March of this year, the $\mathbf{4 0 0}$ megawatt test facility emerged with flying colours from a safety test in which the reactor was shut down from full power, and the main coolantcirculating pumps were turned off. Construction of the Clinch River reactor, say its supporters, is the logical next step.

In approving the Clinch River funding (and therefore channelling support away from solar energy and conservation research which the Science and Technology Committee in the House of Representatives had preferred), the House authorized an initial $\$ 15$ million for the planning of a 1,000 megawatt reactor.

How much future support for the breeder programme will, in fact, be forthcoming from the Reagan Administration remains uncertain. In his formal presentations, budget director David Stockman has forsworn his earlier statements and repeated the Administration's support for LMFBR. In private, however, $\mathrm{Mr}$ Stockman and his officials at the Office of Management and Budget are said to be strongly opposed to further substantial government subsidies of the nuclear industry, including its fast breeder plans, preferring that the utilities should pay.

Meanwhile opponents have not given up the fight. They are giving wide publicity to the findings of a congressional investigation team that some of the contractors may have been overcharging for components already supplied. In the wings is a debate about whether the reactor meets the new siting requirements introduced by the Nuclear Regulatory Commission after the Three Mile Island accident. Congress may have made up its mind, but the public debate is far from over. David Dickson
Research ethics and safety

\section{Changing the guard}

\section{Washington}

In a small but symbolic way, last Thursday may turn out to be a significant turning-point in the history of public controls on genetic engineering. Meeting in Bethesda, Maryland, an advisory committee to the National Institutes of Health (NIH) decided to recommend to its parent body, the Recombinant DNA Advisory Committee (RAC), a further substantial relaxation of the safety controls applied to recombinant DNA research.

Meanwhile 50 miles away, in the depths of the Virginia countryside, a presidential commission established to look at the ethical problems raised by biomedical advances has suggested the establishment of a new body - possibly at an international level - charged to seek a social consensus on the various dilemmas which the expanding clinical use of genetic engineering techniques will raise.

The RAC subcommittee was set up at a meeting of the full committee in May to discuss proposals for a significant relaxation in the safety guidelines made by $\mathrm{Dr}$ David Baltimore of the Massachusetts Institute of Technology and Dr Allan Campbell of Stanford University (Nature 7 May, p.3).

The subcommittee, whose recommendations will now be discussed at the next full meeting of RAC in September, did not agree that NIH guidelines should be made voluntary. However, they did suggest that detailed rules for the composition of local institutional biohazards committees (IBC) be removed.

If eventually approved by $\mathrm{NIH}$, this would mean that research institutions would no longer be required to include "public interest" representatives, for example, on their IBC (although many would probably continue to do so). It could also mean that the responsibilities of the IBC to ensure compliance with the guidelines could be delegated to a single institutional biosafety officer.

The subcommittee also supported a proposal to eliminate from the guidelines a detailed listing of containment procedures, and its replacement by a statement that such procedures should follow recommendations being developed by the Center for Disease Control for experiments using the host or the vector separately.

In other cases the subcommittee proposed that P1 containment levels be used, and that a statement be included about donor DNA, saying that if there is clear evidence that the donor DNA will significantly alter the pathogenicity of the host, then the appropriate containment level will be applied.

Some of the suggestions approved by the subcommittee - for example that all prohibitions requiring special permission from the director of NIH, including work with

\section{Ziman speaks out}

Professor John Ziman on Monday strongly criticized the Royal Society, of which he is a fellow, for sluggishness on human rights issues. He was addressing the All-Party Parliamentary Committee for Soviety Jewry at a special award ceremony in the House of Commons, at which he received on behalf of Dr Viktor Brailovskii, who last month was sentenced to five years' Siberian exile, a Henry Moore lithograph entitled "for courage in defence of freedom".

Professor Ziman earlier this year had received, in conjunction with Dr John Humphrey (until recently deputy director of the National Institute of Medical Research) and lawyer Paul Sieghart, the second annual Airey Neave award, which will finance a study of freedom in science. He was therefore an obvious proxy for $\mathrm{Dr}$ Brailovskii who, until his arrest last November, had acted as host and organizer of the Sunday seminar for Jewish "refusnik" scientists denied emigration visas but dismissed from their academic posts after applying for them.

Professor Ziman said it would have been more appropriate that $\mathrm{Dr}$ Brailovskii's proxy should have been not a private scientist such as himself but the president of the Royal Society in his official capacity. He recalled that $\mathrm{Dr}$ Aleksandr Voronel', the founder of the Sunday seminar, said in Britain shortly after being allowed to emigrate in 1974 that "the seminar is the only true representative of free and independent science in the Soviet Union". The Royal Society, whose official aim is "improving human knowledge", should therefore, said Professor Ziman, give the fullest possible support to the seminar - support which, so far, it has been reluctant to afford.

Vera Rich

cultures over 10 litres, be eliminated from the guidelines - went further than Dr Baltimore and Dr Campbell had proposed to RAC. Others, such as the continuation of local biosafety procedures and the recommendation that the guidelines remain mandatory for scientists working with NIH funds, are more conservative.

Any decisions by RAC at its next meeting will be subsequently published in the Federal Register for public comment. After that, the matter will rest with $\mathrm{Dr}$ Richard M. Krause, director of the National Institute of Allergy and Infectious Diseases, who was given full responsibility for ensuring compliance with the guidelines by $\mathrm{Dr}$ Donald Fredrickson when he resigned as NIH director on 30 June.

As the safety debate is being wound down at NIH, a complementary discussion about the steps necessary to prevent undesirable clinical applications of genetic manipulation techniques has been getting 